\title{
Transcranial direct current stimulation for memory enhancement: from clinical research to animal models
}

\author{
Djamila Bennabi ${ }^{1+}$, Solène Pedron ${ }^{1+}$, Emmanuel Haffen ${ }^{1,2}$, Julie Monnin ${ }^{1,2}$, Yvan Peterschmitt ${ }^{1}$ and \\ Vincent Van Waes ${ }^{1 *}$
}

EA 481 Laboratory of Integrative and Clinical Neuroscience, University of Franche-Comté/SFR FED 4234, Besançon, France

2 INSERM CIC-IT 808 Clinical Investigation Centre for Innovative Technology, University Hospital of Besançon, Besançon, France

\section{Edited by:}

Ioan Opris, Wake Forest University, USA

\section{Reviewed by:}

Berthold Langguth, University of

Regensburg, Germany

Estate M. Sokhadze, University of

Louisville, USA

*Correspondence:

Vincent Van Waes, EA 481

Laboratory of Integrative and Clinical

Neuroscience, University of

Franche-Comté - UFR Sciences et

Techniques, 2 Place Leclerc, 25030

Besançon, France

e-mail:vincent.van_waes@

univ-fcomte.fr

${ }^{\dagger}$ Co-first authors.
There is a growing demand for new brain-enhancing technologies to improve mental performance, both for patients with cognitive disorders and for healthy individuals. Transcranial direct current stimulation (tDCS) is a non-invasive, painless, and easy to use neuromodulatory technique that can improve performance on a variety of cognitive tasks in humans despite its exact mode of action remains unclear. We have conducted a mini-review of the literature to first briefly summarize the growing amount of data from clinical trials assessing the efficacy of tDCS, focusing exclusively on learning and memory performances in healthy human subjects and in patients with depression, schizophrenia, and other neurological disorders. We then discuss these findings in the context of the strikingly few studies resulting from animal research. Finally, we highlight future directions and limitations in this field and emphasize the need to develop translational studies to better understand how tDCS improves memory, a necessary condition before it can be used as a therapeutic tool.

Keywords: tDCS, neuromodulation, prefrontal cortex, cognitive enhancement, memory
Non-invasive neuromodulatory techniques including tDCS have been shown to improve performance on a variety of cognitive domains. tDCS is a painless stimulation method that delivers subthreshold electrical currents to the brain and manipulates the resting membrane potential of cortical neurons (e.g., Stagg and Nitsche, 2011). Since the dorsolateral prefrontal cortex (DLPFC) is a crucial element in the neural network subserving executive functions (i.e., working memory, planning, goal-oriented behavior, attention, and inhibitory control; Wood and Grafman, 2003), targeting this area with neuromodulatory techniques represents a promising therapeutic option for improving cognition. In this mini-review, we summarize data obtained from clinical trials (see Tables 1A, B) and animal models focusing on tDCS-induced memory enhancement in healthy subjects and in subjects with psychiatric and neurological disorders known to induce mild to severe cognition impairments. Limitations and perspectives are then discussed.

\section{HUMAN STUDIES \\ tDCS FOR COGNITIVE ENHANCEMENT IN HEALTHY SUBJECTS}

To date, most studies conducted in healthy individuals have assessed the effect of tDCS in enhancing verbal and visuospatial components of working memory (WM) and learning processes. Fregni et al. found that online anodal tDCS at $1 \mathrm{~mA}$ applied over the left DLPFC enhances accuracy in a three-back letter task compared with cathodal stimulation of the same area or anodal stimulation of the primary motor cortex (Fregni et al., 2005). Based on the same paradigm, Ohn et al. investigated the timedependency of tDCS and found an increased number of correct responses starting $20 \mathrm{~min}$ after the beginning of active stimulation compared to sham, whereas earlier measurements did not reveal any stimulation effects (Ohn et al., 2008). More recently, Lally et al. confirmed these results in a larger cohort, but only when subjects were tested during the stimulation session (online), without a persisting effect $48 \mathrm{~h}$ later (Lally et al., 2013). Mulquiney et al. obtained discordant results in a sample of 10 healthy volunteers, with no improvement in accuracy but in speed performance after anodal tDCS (Mulquiney et al., 2011). However, Marshall et al. reported increased reaction time in the same task during both anodal and cathodal bilateral intermittent stimulation over the DLPFC (Marshall et al., 2005). Andrews and collaborators investigated the impact of 1 session of anodal tDCS delivered during a WM task (n-back task) on performances on a subsequent WM task (digit span forward) (Andrews et al., 2011). Upon completion of the n-back task, they observed a significant improvement in performance on the digit span forward task. Berryhill and Jones enhanced WM by application of anodal tDCS over the left or right DLPFC in subjects with a high educational level, whereas tDCS provided no benefit in WM performance to a less educated group (Berryhill and Jones, 2012). Interestingly, Teo et al. found that WM performances are influenced by current strength of anodal tDCS (Teo et al., 2011). Gladwin et al. explored the impact of anodal left DLPFC tDCS on Sternberg task completion when distractor stimuli were presented during the retention period. tDCS improved reaction time only when the incorrect choice had been a distractor suggesting stimulation might have an effect on selective attention. In a subsequent study, they showed that tDCS improves reaction time in an implicit association test 
Table 1A | Studies investigating the cognitive effects of tDCS in healthy subjects.

\begin{tabular}{|c|c|c|c|c|c|c|c|c|c|}
\hline \multicolumn{5}{|c|}{ Study } & \multicolumn{4}{|c|}{ tDCS parameters } & \multirow[t]{2}{*}{ Results } \\
\hline Author & Design & $\mathbf{n}$ & Task & & $A / C$ & I (mA) & $\mathrm{D}(\min )$ & $E\left(\mathrm{~cm}^{2}\right)$ & \\
\hline $\begin{array}{l}\text { Fregni et al., } \\
2005\end{array}$ & $\begin{array}{l}\text { Cross over } \\
\text { Single blind }\end{array}$ & 15 & n-back task & Online & F3/FP2 & 1 & 10 & 35 & $\begin{array}{l}\text { Improvement in accuracy (more correct } \\
\text { responses) } \\
\text { No improvement in reaction time }\end{array}$ \\
\hline Ohn et al., 2008 & $\begin{array}{l}\text { Cross over } \\
\text { Single blind }\end{array}$ & 15 & n-back task & $\begin{array}{l}\text { Online } \\
\text { Offline }\end{array}$ & F3/FP2 & 1 & 20 & 35 & $\begin{array}{l}\text { Increased number of correct responses after } \\
30 \text { min of stimulation with anodal stimulation }\end{array}$ \\
\hline Lally et al., 2013 & $\begin{array}{l}\text { Cross over } \\
\text { Double blind }\end{array}$ & 21 & n-back task & $\begin{array}{l}\text { Online } \\
\text { Offline }\end{array}$ & F3/cheek & 1 & 10 & 35 & $\begin{array}{l}\text { Improvement of performance during the first } \\
\text { stimulation phase with active stimulation }\end{array}$ \\
\hline $\begin{array}{l}\text { Mulquiney et al., } \\
2011\end{array}$ & Cross over & 10 & $\begin{array}{l}\text { Cogstate } \\
\text { Sternberg } \\
\text { task }\end{array}$ & $\begin{array}{l}\text { Online } \\
\text { Offline }\end{array}$ & F3/FP2 & 1 & 10 & 35 & $\begin{array}{l}\text { 2-back task: no effects of session or time in } \\
\text { accuracy; improvement in reaction time } \\
\text { Sternberg task: no effect of session or time }\end{array}$ \\
\hline $\begin{array}{l}\text { Marshall et al., } \\
2005\end{array}$ & $\begin{array}{l}\text { Cross over } \\
\text { Double blind }\end{array}$ & 12 & $\begin{array}{l}\text { Modified } \\
\text { Sternberg } \\
\text { task }\end{array}$ & Online & F3/F4 & 0.26 & 15 & 64 & $\begin{array}{l}\text { No improvement in accuracy } \\
\text { Slower reaction time after anodal and cathodal } \\
\text { tDCS }\end{array}$ \\
\hline $\begin{array}{l}\text { Andrews et al., } \\
2011\end{array}$ & Cross over & 10 & $\begin{array}{l}\text { n-back task } \\
\text { Digit span } \\
\text { tasks }\end{array}$ & $\begin{array}{l}\text { Online } \\
\text { Offline }\end{array}$ & F3/FP2 & 1 & 10 & 35 & $\begin{array}{l}\text { Previous application of tDCS during the n-back } \\
\text { task resulted in increased performance on digit } \\
\text { span forward }\end{array}$ \\
\hline $\begin{array}{l}\text { Berryhill and } \\
\text { Jones, } 2012\end{array}$ & Cross over & 25 & n-back task & Offline & $\begin{array}{l}\text { F3/cheek } \\
\text { F4/cheek }\end{array}$ & 1.5 & 10 & 35 & $\begin{array}{l}\text { Low education group: unchanged or impaired } \\
\text { performance } \\
\text { High education group: improved performance }\end{array}$ \\
\hline Teo et al., 2011 & $\begin{array}{l}\text { Cross over } \\
\text { Double blind }\end{array}$ & 12 & $\begin{array}{l}\text { n-back task } \\
\text { Sternberg } \\
\text { task }\end{array}$ & $\begin{array}{l}\text { Online } \\
\text { Offline }\end{array}$ & F3/FP2 & 1 or 2 & 20 & 35 & $\begin{array}{l}\text { n-back task: decrease reaction time during the } \\
\text { last } 5 \text { min of } 2 \mathrm{~mA} \text { session. } \\
\text { Sternberg task: no difference in reaction time } \\
\text { and accuracy between } 1 \mathrm{~mA}, 2 \mathrm{~mA} \text {, or sham } \\
\text { stimulation }\end{array}$ \\
\hline $\begin{array}{l}\text { Gladwin et al., } \\
2012 a\end{array}$ & Cross over & 14 & $\begin{array}{l}\text { Sternberg } \\
\text { task }\end{array}$ & $\begin{array}{l}\text { Online } \\
\text { Offline }\end{array}$ & F3/FP2 & 1 & 10 & 35 & $\begin{array}{l}\text { Improvement in reaction time, influence of } \\
\text { interference }\end{array}$ \\
\hline $\begin{array}{l}\text { Gladwin et al., } \\
2012 b\end{array}$ & Cross over & 20 & $\begin{array}{l}\text { Modified } \\
\text { version of } \\
\text { the IAT }\end{array}$ & Offline & F3/FP2 & 1 & 10 & 35 & $\begin{array}{l}\text { Improvement in reaction time in the congruent } \\
\text { rather than in the incongruent condition }\end{array}$ \\
\hline $\begin{array}{l}\text { Kincses et al., } \\
2004\end{array}$ & Cross over & 14 & PCL & Online & $\mathrm{F} 3 / \mathrm{Cz}$ & 1 & 10 & 35 & $\begin{array}{l}\text { Improvement of implicit learning by anodal but } \\
\text { not cathodal stimulation }\end{array}$ \\
\hline $\begin{array}{l}\text { Hammer et al., } \\
2011\end{array}$ & $\begin{array}{l}\text { Cross over } \\
\text { Single blind }\end{array}$ & 36 & $\begin{array}{l}\text { Recognition } \\
\text { memory } \\
\text { task }\end{array}$ & $\begin{array}{l}\text { Online } \\
\text { Offline }\end{array}$ & F3/FP2 & 1 & 30 & 35 & $\begin{array}{l}\text { Cathodal stimulation hampered memory } \\
\text { performance after errorful learning, whereas } \\
\text { anodal stimulation did not alter encoding and } \\
\text { memory retrieval }\end{array}$ \\
\hline $\begin{array}{l}\text { Manenti et al., } \\
2013\end{array}$ & $\begin{array}{l}\text { Cross over } \\
\text { Single blind }\end{array}$ & 64 & $\begin{array}{l}\text { Episodic } \\
\text { memory } \\
\text { task }\end{array}$ & Online & F3/F4 & 1.5 & 6 & 35 & $\begin{array}{l}\text { Improvement of verbal episodic memory with } \\
\text { anodal tDCS applied during the retrieval phase } \\
\text { Better performances in young subjects }\end{array}$ \\
\hline $\begin{array}{l}\text { Zwissler et al., } \\
2014\end{array}$ & $\begin{array}{l}\text { Cross over } \\
\text { Double blind }\end{array}$ & 85 & $\begin{array}{l}\text { Episodic } \\
\text { memory } \\
\text { task }\end{array}$ & Online & $\begin{array}{l}\text { F3/con- } \\
\text { tralateral } \\
\text { musculus } \\
\text { deltoideus }\end{array}$ & 1 & 15 & 35 & $\begin{array}{l}\text { Anodal tDCS increased whereas cathodal } \\
\text { stimulation decreased the number of false } \\
\text { alarms to lure pictures in subsequent } \\
\text { recognition memory testing }\end{array}$ \\
\hline
\end{tabular}

Cz, midline central (international 10/20 EEG system); F3, left dorsolateral prefrontal cortex; F4, right dorsolateral prefrontal cortex; FP2, supraorbital right; IAT, Implicit Association Test; PCL, probabilistic classification learning; I, intensity; D, duration; E, electrodes size. 
Table 1B | Studies investigating the cognitive effects of tDCS in psychiatric diseases.

\begin{tabular}{|c|c|c|c|c|c|c|c|c|c|}
\hline \multicolumn{5}{|c|}{ Study } & \multicolumn{4}{|c|}{ tDCS parameters } & \multirow[t]{2}{*}{ Results } \\
\hline Author & Design & $\mathbf{n}$ & Task & & $A / C$ & I (mA) & $\mathrm{D}(\mathrm{min})$ & $E\left(\mathrm{~cm}^{2}\right)$ & \\
\hline \multicolumn{10}{|l|}{ DEPRESSION } \\
\hline $\begin{array}{l}\text { Brunoni et al., } \\
2013\end{array}$ & $\begin{array}{l}\text { Double blind } \\
\text { RCT }\end{array}$ & $28 \cup P$ & $\begin{array}{l}\text { Probabilistic } \\
\text { classification learning }\end{array}$ & Online & F3/F4 & 2 & 30 & 25 & $\begin{array}{l}\text { No improvement in implicit } \\
\text { learning after real stimulation }\end{array}$ \\
\hline $\begin{array}{l}\text { Fregni et al., } \\
2006\end{array}$ & $\begin{array}{l}\text { Double blind } \\
\text { RCT }\end{array}$ & $18 \cup P$ & $\begin{array}{l}\text { Digit span forward } \\
\text { and backward test }\end{array}$ & Online & F3/FP2 & 1 & 10 & 35 & $\begin{array}{l}\text { Improvement in working } \\
\text { memory }\end{array}$ \\
\hline $\begin{array}{l}\text { Oliveira et al., } \\
2013\end{array}$ & $\begin{array}{l}\text { Double blind } \\
\text { RCT }\end{array}$ & $28 \cup P$ & n-back task & Online & F3/F4 & 2 & 30 & 25 & $\begin{array}{l}\text { Enhancement of working } \\
\text { memory } \\
\text { Increase rate of correct } \\
\text { responses } \\
\text { Increase ability to discriminate } \\
\text { between correct responses and } \\
\text { false alarms }\end{array}$ \\
\hline $\begin{array}{l}\text { Wolkenstein and } \\
\text { Plewnia, } 2013\end{array}$ & $\begin{array}{l}\text { Double blind } \\
\text { RCT }\end{array}$ & $22 \mathrm{MDD}$ & $\begin{array}{l}\text { Delayed- response } \\
\text { working memory } \\
\text { task }\end{array}$ & Online & $\begin{array}{l}\text { F3/Right } \\
\text { upper arm }\end{array}$ & 1 & 20 & 35 & $\begin{array}{l}\text { Enhancement of working } \\
\text { memory performance and } \\
\text { elimination of attentional bias }\end{array}$ \\
\hline $\begin{array}{l}\text { Ferrucci et al., } \\
2009\end{array}$ & Open label & $8 \mathrm{MDD}$ & $\begin{array}{l}\text { Sternberg Task } \\
\text { Word recognition } \\
\text { task } \\
\text { Posner paradigm }\end{array}$ & Offline & F3/F4 & 2 & 20 & 32 & $\begin{array}{l}\text { Cognitive tasks showed no } \\
\text { significant difference between } \\
\text { active or sham stimulation }\end{array}$ \\
\hline Loo et al., 2012 & $\begin{array}{l}\text { Double blind } \\
\text { RCT }\end{array}$ & 64 MDD & $\begin{array}{l}\text { RAVLT, Stroop Test, } \\
\text { COWAT, Digit span, } \\
\text { SDMT }\end{array}$ & Offline & F3/F8 & 2 & 20 & 35 & $\begin{array}{l}\text { Improvement of working } \\
\text { memory performances, indexed } \\
\text { by the SDMT, after } 1 \text { tDCS } \\
\text { session } \\
\text { No improvement in cognitive } \\
\text { performances after } 15 \text { sessions }\end{array}$ \\
\hline Palm et al., 2012 & $\begin{array}{l}\text { Double blind } \\
\text { RCT }\end{array}$ & 22 MDD & VLMT, RWT LNSWAIS & Offline & F3/FP2 & 1 or 2 & 20 & 35 & $\begin{array}{l}\text { Cognitive tasks showed no } \\
\text { significant difference between } \\
\text { active or sham stimulation }\end{array}$ \\
\hline \multicolumn{10}{|l|}{ SCHIZOPHRENIA } \\
\hline $\begin{array}{l}\text { Vercammen } \\
\text { et al., } 2011\end{array}$ & $\begin{array}{l}\text { Single blind } \\
\text { Cross over }\end{array}$ & 20 & $\begin{array}{l}\text { Probabilistic } \\
\text { classification learning }\end{array}$ & Online & F3/FP2 & 2 & 20 & 35 & $\begin{array}{l}\text { Improvement in implicit learning } \\
\text { after real stimulation in a subset } \\
\text { of patient }\end{array}$ \\
\hline Hoy et al., 2014 & $\begin{array}{l}\text { Double blind } \\
\text { RCT }\end{array}$ & 18 & nback & Offline & F3/FP2 & 1 or 2 & 20 & & $\begin{array}{l}\text { Improvement in working } \\
\text { memory at } 2 \mathrm{~mA}\end{array}$ \\
\hline $\begin{array}{l}\text { Goder et al., } \\
2013\end{array}$ & Cross over & 14 & RAVLT & Offline & F3/F4 & $0-0.3$ & $\begin{array}{l}\text { During } \\
\text { sleep }\end{array}$ & 64 & $\begin{array}{l}\text { Improvement in working } \\
\text { memory }\end{array}$ \\
\hline \multicolumn{10}{|l|}{ ALZHEIMER } \\
\hline $\begin{array}{l}\text { Boggio et al., } \\
2009\end{array}$ & $\begin{array}{l}\text { Double blind } \\
\text { RCT }\end{array}$ & 10 & $\begin{array}{l}\text { Digit span test } \\
\text { Visual recognition } \\
\text { Memory task } \\
\text { Stroop test }\end{array}$ & Online & $\begin{array}{l}\text { F3/ FP2 } \\
\text { T7/FP2 }\end{array}$ & 2 & 30 & 35 & $\begin{array}{l}\text { Improvement in working } \\
\text { memory after prefrontal and } \\
\text { temporal stimulation } \\
\text { No effect on digit span and } \\
\text { Stroop performance }\end{array}$ \\
\hline $\begin{array}{l}\text { Cotelli et al., } \\
2014\end{array}$ & $\begin{array}{l}\text { Double blind } \\
\text { RCT }\end{array}$ & $\begin{array}{l}36 \\
\text { (mild to } \\
\text { moder- } \\
\text { ate) }\end{array}$ & $\begin{array}{l}\text { Face-name } \\
\text { association memory } \\
\text { task } \\
\text { Memory training }\end{array}$ & Offline & $\begin{array}{l}\text { F3/Right } \\
\text { deltoid } \\
\text { muscle }\end{array}$ & 2 & 24 & & $\begin{array}{l}\text { No additive effects of anodal } \\
\text { tDCS on memory performance } \\
\text { when combined with memory } \\
\text { training }\end{array}$ \\
\hline
\end{tabular}


Table 1B | Continued

\begin{tabular}{|c|c|c|c|c|c|c|c|c|c|}
\hline \multicolumn{5}{|c|}{ Study } & \multicolumn{4}{|c|}{ tDCS parameters } & \multirow[t]{2}{*}{ Results } \\
\hline Author & Design & $\mathbf{n}$ & Task & & $A / C$ & I (mA) & $D(\min )$ & $E\left(\mathrm{~cm}^{2}\right)$ & \\
\hline \multicolumn{10}{|l|}{ PARKINSON } \\
\hline $\begin{array}{l}\text { Boggio et al., } \\
2006\end{array}$ & $\begin{array}{l}\text { Double blind } \\
\text { RCT }\end{array}$ & 18 & n-back task & Online & F3/ FP2 & 1 or 2 & 20 & 35 & $\begin{array}{l}\text { Improvement in accuracy } \\
\text { No improvement in reaction } \\
\text { time } \\
\text { No effect at } 1 \mathrm{~mA}\end{array}$ \\
\hline $\begin{array}{l}\text { Pereira et al., } \\
2013\end{array}$ & Cross over & 16 & $\begin{array}{l}\text { Semantic fluency } \\
\text { task phonemic task }\end{array}$ & Offline & $\begin{array}{l}\text { F3/FP2 } \\
\text { P3-T5/FP2 }\end{array}$ & 2 & 20 & 35 & $\begin{array}{l}\text { Improvement in the phonemic } \\
\text { fluency task after DLPFC tDCS }\end{array}$ \\
\hline \multicolumn{10}{|l|}{ POST-STROKE } \\
\hline Kang et al., 2009 & $\begin{array}{l}\text { Double blind } \\
\text { RCT }\end{array}$ & 10 & Go/No-Go & Offline & F3/FP2 & 2 & 20 & 25 & $\begin{array}{l}\text { Improvement in response } \\
\text { accuracy at } 1 \text { and } 3 \mathrm{~h} \\
\text { post-stimulation }\end{array}$ \\
\hline Jo et al., 2009 & $\begin{array}{l}\text { Double blind } \\
\text { RCT }\end{array}$ & 10 & n-back task & Offline & F3/FP2 & 2 & 30 & 35 & $\begin{array}{l}\text { Improvement in the two-back } \\
\text { task after DLPFC tDCS }\end{array}$ \\
\hline Park et al., 2013 & $\begin{array}{l}\text { Double blind } \\
\text { RCT }\end{array}$ & 11 & $\begin{array}{l}\text { Seoul computerized } \\
\text { neuropsychological } \\
\text { test }\end{array}$ & Offline & F3/F4 & 2 & 30 & 25 & $\begin{array}{l}\text { Improvement in attention when } \\
\text { combined with cognitive } \\
\text { rehabilitation }\end{array}$ \\
\hline
\end{tabular}

COWAT, Controlled Oral Word Association Test; F3, left dorsolateral prefrontal cortex (international 10/20 EEG system); F4, right dorsolateral prefrontal cortex; FP2, supraorbital right; F8, lateral aspect of the right orbit; LNS WAIS, Letter Number Sequencing Task of the Wechsler Adult Intelligence Scale; MDD, Major Depressive Disorder; RAVLT, Ray Auditory Verbal Learning Test; RCT, Randomized Controlled Trial; RWT, Regensburg Word Fluency Test; SDMT, Symbol Digit Modalities Test; UP, Unipolar Depression; I, intensity; D, duration; E, electrodes size; VLMT, Verbal Learning Memory Test, P3-T5, left temporo-parietal cortex.

without affecting the subjects' ability to overcome bias (Gladwin et al., 2012a,b).

In addition, tDCS has been recently used as an investigative tool in other memory domains. With regard to implicit memory (probabilistic classification learning), Kincses et al. first demonstrated that anodal tDCS performed over the left DLPFC at $1 \mathrm{~mA}$ in healthy volunteers resulted in immediate improvement in implicit learning (Kincses et al., 2004). Hammer et al. showed that cathodal stimulation hampered memory performance after errorful learning, whereas anodal stimulation did not alter encoding and memory retrieval (Hammer et al., 2011). Manenti et al. found that anodal stimulation enhances the long-term episodic memory capacities of young and older subjects with more robust effects in young participants (Manenti et al., 2013). Plewnia and collaborators also reported that tDCS shapes accuracy of episodic memory via polaritiy-specific modulation of false recognition. When applied during encoding of pictures, anodal tDCS increased whereas cathodal stimulation reduced the number of false alarms (i.e., responses to highly similar distracter images) in subsequent recognition memory testing (Zwissler et al., 2014).

\section{tDCS FOR COGNITIVE ENHANCEMENT IN PSYCHIATRIC AND NEUROLOGICAL DISORDERS}

Bifrontal tDCS has been shown to prevent procedural learning in depressive states, possibly by inducing a decrease in the activity of the right DLPFC (Brunoni et al., 2013). Beneficial effects of online stimulation applied over the left DLPFC have been reported for working memory, attentional performances, and information processing in depressed patients (Fregni et al., 2006;
Oliveira et al., 2013; Wolkenstein and Plewnia, 2013). However, two randomized controlled trials and one open-label trial failed to replicate this finding with offline stimulation, suggesting that multiple tDCS sessions do not have cumulative cognitive enhancing effects (Ferrucci et al., 2009; Loo et al., 2012; Palm et al., 2012).

Only a small number of studies have examined the impact of tDCS on selective cognitive domains altered in schizophrenia. Focusing on working memory, Vercammen et al. reported that a single session of anodal tDCS to the left DLPCF improves probabilistic association learning in a specific subset of schizophrenic patients (Vercammen et al., 2011). These findings were interpreted as an enhancement of DLPFC function primarily in individuals with relatively higher neural and cognitive reserve. Hoy et al. observed the same tDCS effects on a working memory task after a $2 \mathrm{~mA}$ stimulation (Hoy et al., 2014). Göder et al. showed improved sleep-associated memory consolidation in patients with schizophrenia when anodal tDCS oscillating at a frequency of $0.75 \mathrm{~Hz}$ was applied during sleep (Goder et al., 2013).

Cognitive enhancing properties of tDCS have also been explored in a number of neurological diseases. For example, in Alzheimer disease, Boggio et al. (2009) reported short-term facilitation effects on visual recognition memory after prefrontal and temporal anodal tDCS applied $30 \mathrm{~min}$ at $2 \mathrm{~mA}$, with no changes in attention. More recently, Cotelli et al. demonstrated that repeated sessions of anodal tDCS to the left DLFPC plus computerized memory training led to an increase in performance in a facename association task (Cotelli et al., 2014). However, combined treatment failed to ameliorate the memory performance more 
than memory training alone suggesting an absence of effects of tDCS in this paradigm. It has also been shown that a single tDCS session can ameliorate memory deficits in Parkinson's disease. Boggio et al. enhanced WM by application of anodal tDCS over the left DPFC at $2 \mathrm{~mA}$, whereas stimulation with intensities of $1 \mathrm{~mA}$ or of other area (motor cortex) provided no benefit in WM performance (Boggio et al., 2006). Pereira et al. found that anodal tDCS (at $2 \mathrm{~mA}$ ) applied over the left DLPFC enhanced performance and functional connectivity in task-related networks in a verbal fluency task tested during fMRI (Pereira et al., 2013).

Kang et al. reported increased response accuracy in a Go/NoGo task tested 1 and $3 \mathrm{~h}$ after anodal stimulation at $2 \mathrm{~mA}$ over the DLPFC in 10 patients with post-stroke cognitive decline (MMSE $\leq 25$ ) (Kang et al., 2009). Jo et al. also reported that 10 patients with subacute stroke achieved a significant improvement in the accuracy of verbal two-back working memory after receiving the tDCS to the left prefrontal cortex at an intensity of $2 \mathrm{~mA}$ for $30 \mathrm{~min}$ (Jo et al., 2009). Park et al. found that the concomitant use of anodal tDCS with a computer-assisted cognitive rehabilitation program had a significant effect on improving attention in post-stroke patients with mild-to-moderate cognitive dysfunction (Park et al., 2013).

In spite of the increasing number of clinical studies showing beneficial effects of prefrontal tDCS on the domains of learning and memory, its mechanism of action remains unclear. Recent clinical studies have started to tackle this question (e.g., Keeser et al., 2011a,b; Amadi et al., 2013; Dayan et al., 2013; Palm et al., 2013; Plewnia et al., 2013; Stagg and Johansen-Berg, 2013); however, the cellular mechanisms underlying tDCS will likely require the use of animal models.

\section{ANIMAL MODELS OF tDCS}

Animal models provide a powerful tool to identify the mechanisms by which tDCS modulates neural network function to support improved cognition. In rats, tDCS was first used to evaluate the safety limits of cathodal stimulations (Liebetanz et al., 2009) and to map brain activation patterns after tDCS (Takano et al., 2011). In the latter study, the authors observed significantly increased fMRI signal intensities in the frontal cortex and nucleus accumbens of rats after anodal tDCS (of the frontal lobe), suggesting that $\mathrm{tDCS}$ induces neuronal activation both in cortical and subcortical areas. To date, few animal studies have addressed the impact of tDCS on learning and memory processes.

\section{tDCS FOR COGNITIVE ENHANCEMENT IN HEALTHY ANIMALS}

Similar to humans, the prefrontal cortex (or more generally speaking, the frontal lobe) has been the main target of animal studies for its implication in working memory. In a recent paper, Dockery et al. performed experiments in rats using the Allothetic Place Avoidance Alternation Task (APAAT), a behavioral model of visuospatial working memory and skill learning (Dockery et al., 2011). In this paradigm, a recent memory is engaged by the necessity to remember the location of a to-be-avoided sector (punished by an electric shock), which is alternated daily. tDCS on the frontal lobe $(30 \mathrm{~min} /$ day before the APAAT task [ 3 days in total], $200 \mu \mathrm{A}$, epicranial electrode: $3.5 \mathrm{~mm}^{2}$ over the frontal lobe, counter electrode: $10.5 \mathrm{~cm}^{2}$ placed between the shoulders) had no measurable short-term effect on on-going place avoidance learning. However, in a follow-up session (18 days after the last APAAT session), the rats previously treated with cathodal (but not anodal) tDCS showed significantly more efficient place avoidance and skill retention compared to controls. Other types of memory, such as associative learning processes, can also be affected by tDCS (Marquez-Ruiz et al., 2012). In this case, tDCS was applied to behaving rabbits via four silver-ball stimulating electrodes ( $1 \mathrm{~mm}$ in diameter, placed symmetrically above the skull $3 \mathrm{~mm}$ from the right $\mathrm{S} 1$ vibrissa area on the somatosensory cortex) with a saline-soaked sponge $\left(35 \mathrm{~cm}^{2}\right.$ surface area) attached to the contralateral ear serving as the counter electrode. The authors found that the acquisition of classical eyeblink conditioning is potentiated or depressed by the simultaneous application of anodal or cathodal tDCS, respectively, when stimulation of the whisker pad was used as a conditioned stimulus. These results suggest that tDCS modulates the sensory perception processes necessary for this type of associative learning (Marquez-Ruiz et al., 2012).

Recently, we have adapted a model of tDCS in mice and tested its validity in a wide range of behavioral paradigms (Pedron et al., 2014). We applied repeated anodal tDCS over the left frontal cortex of the mouse (see, Figures 1A,B) and used a $2 \times 20 \mathrm{~min} /$ day stimulation paradigm at $200 \mu \mathrm{A}$ for 5 consecutive days. In agreement with human studies, our data suggest that repeated anodal tDCS improves long-term spatial memory (in the Morris water maze, Figure 1C) and working memory (object recognition, Figure 1D) without affecting behaviors such as locomotor activity and anxiety-related behaviors (Pedron et al., 2014).

Finally, Marshall and collaborators have investigated the interaction of tDCS with hippocampo-neocortical rhythms and reported that a transcranial slow oscillation stimulation during sleep enhances memory consolidation in rats (anodes: bilaterally over the prefrontal cortex; return electrodes: over the cerebellum; sinusoidal constant current fluctuating between 0 and $5.6 \mu \mathrm{A}$ at a frequency of $1.5 \mathrm{~Hz}$ applied during non-rapid eyes movement sleep) (Binder et al., 2014a,b).

\section{COGNITIVE ENHANCEMENT IN ANIMAL MODELS OF NEUROLOGICAL DISORDERS}

To the best of our knowledge, tDCS has yet to be tested for enhancing cognition in animal models of psychiatric disorders, but it has been shown to facilitate recovery from cognitive impairments induced by stroke or status epilepticus in rats. After cerebral ischemia, Yoon et al. employed a cup-shaped anodal stimulation electrode positioned at the ischemic borderline, and a rectangular rubber cathodal electrode $(80 \times 60 \mathrm{~mm})$ fixed on the anterior chest (Yoon et al., 2012) to inject a direct current at an intensity of $200 \mu \mathrm{A}$ for $20 \mathrm{~min}$, once a day for 5 consecutive days. Both early ( 1 day) and late ( 1 week after ischemic injury) treatment had a beneficial outcome on cognition (spatial memory evaluated in the Barnes maze test) without exacerbating ischemic volume. Interestingly, this effect was not present 1 day after tDCS, but began to appear 2 weeks after the stimulations and was maximal after 4 weeks. Therapeutic effects of tDCS on cognition were associated with an increase in the 
A

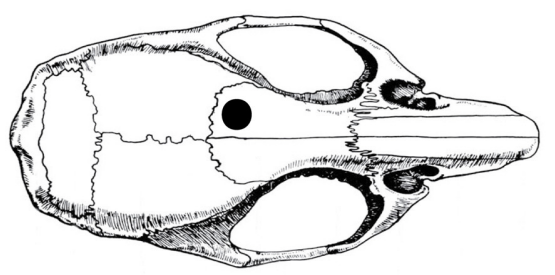

C long-term spatial memory

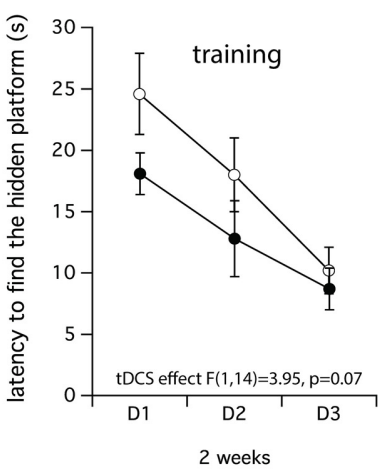

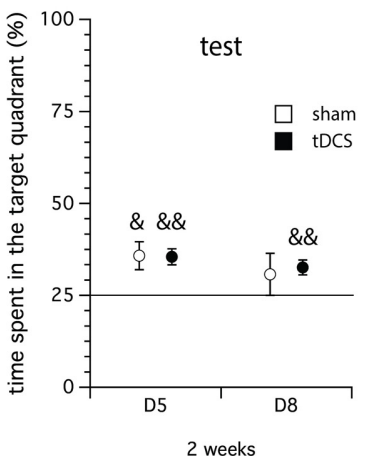

B

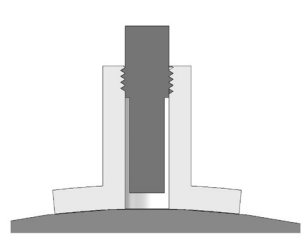

D working memory (2 $\mathrm{min})$

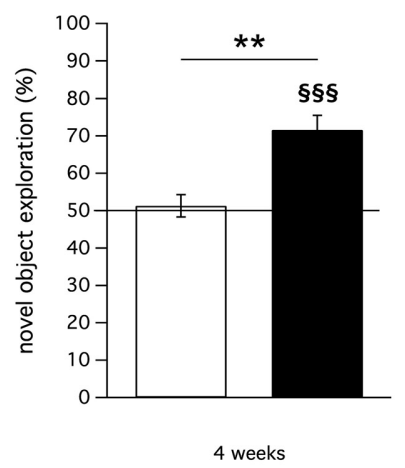

FIGURE 1 | Illustration of the tDCS device used to deliver the electrical stimulation in mice (Pedron et al., 2014) and main results obtained on cognition. (A) The center of the stimulation electrode (anode) is positioned over the left frontal cortex $1 \mathrm{~mm}$ anterior to the coronal fissure and $1 \mathrm{~mm}$ left of the sagittal fissure (Paxinos and Franklin, 2001). The cathode (rubber-plate electrode, $9.5 \mathrm{~cm}^{2}$ ) is placed onto the ventral thorax (not shown). (B) Anode: A tubular plastic jacket (internal diameter: $2.1 \mathrm{~mm}$ ) is surgically fixed onto the skull and filled with saline solution before the stimulation. The stimulation electrode is screwed into the tubular plastic jacket and immersed in the saline solution. Only the saline solution is in contact with the skull. (C) Four month-old Swiss female mice were subjected to repeated anodal tDCS for 5 consecutive days $(2 \times 20 \mathrm{~min} /$ day constant current, $0.2 \mathrm{~mA}$ ). Long-term spatial memory was evaluated 2 weeks after the last stimulation in the Morris water navigation task (training: left; test: right). tDCS significantly improved long-term spatial memory. (D) Effect of repeated anodal tDCS on working memory evaluated in an object recognition task (inter-trial interval: 2 min) 4 weeks after the last stimulation. The novel object exploration (score in \%) was significantly higher than $50 \%$ in the tDCS group, reflecting a better working memory performance compared to sham group for which the score was not significantly different than $50 \% . \&_{p}<0.05$ and $\& \& p<0.01$ vs. $25 \%,{ }^{* *} p<0.01$ vs. sham, ${ }^{\S \S} p<0.001$ vs. $50 \% ; N=8$ per group. expression of Map-2 (a stabilizer of microtubules growth) and Gap-43 (a neuronal growth-promoting gene) in the early treatment group and in the late treatment group, respectively, in both peri-lesional and contra-lesional cortex. Kamida et al. used cathodal tDCS $(1.5 \mathrm{~mm}$ to the right, $2 \mathrm{~mm}$ anterior from bregma; counter electrode: $1 \mathrm{~cm}$ needle electrode inserted into the back of the neck, $30 \mathrm{~min}$ per day for 2 weeks at $200 \mu \mathrm{A}$ ) to evaluate its effect on seizures and spatial memory deficits following pilocarpine-induced status epilepticus in immature rats (Kamida et al., 2011). Repeated cathodal tDCS reduced seizures, spatial memory impairments, status epilepticus-induced hippocampal cell loss, and supragranular and CA3 mossy fiber sprouting.

\section{POTENTIAL MECHANISMS OF ACTION AND PERSPECTIVES CANDIDATE MECHANISMS UNDERLYING tDCS ACTION ON COGNITION}

To date, it is known that tDCS modifies the resting membrane potential when online and induces prolonged offline after-effects similar to long-term potentiation/depression (Paulus, 2004), considered to be the cellular mechanisms of learning and memory. For example, in humans the long-lasting effects of tDCS (both anodal and cathodal) on the primary motor cortex are suppressed after NMDA-receptor blockade indicating a dependence on glutamatergic activity (Liebetanz et al., 2002). Moreover, previous experiments in rats have shown that anodal polarization directly applied to the cortex has the ability to modulate neural plasticity (i.e., c-Fos activation) via activation of NMDA receptors (Islam et al., 1995).

Our team has started to investigate the role of adult neurogenesis as a mechanism involved in tDCS action. Neurogenesis in the hippocampus is of particular interest as tDCS induces both antidepressant effects and enhances cognition in humans and mice, two phenomena critically linked to the generation of new neurons in the adult dentate gyrus (Deng et al., 2010; Eisch and Petrik, 2012). In addition, the time course for the onset of long term tDCS effect on depression-related behavior and on cognition in our animal model (after several weeks, Pedron et al., 2014) is consistent with the delay necessary for newly generated cells in the hippocampus to be functionally integrated (Klempin et al., 2010). Of particular interest is the impact of tDCS on brain-derived neurotrophic factor (BDNF) levels. This growth factor is important for long-term memory (Bekinschtein et al., 2008), is involved in depressive-like behaviors and antidepressant drug action, and can modulate neurogenesis levels (Castren and Rantamaki, 2010; Vithlani et al., 2013). A recent study has shown that BDNF activation is necessary for DCS-induced long-term potentiation in mouse M1 slices 
(Fritsch et al., 2010). Enhancement of motor skill acquisition by anodal tDCS also seems to be related to BDNF, as the BDNF val66met polymorphism in humans is associated with decreased proclivity to tDCS-induced benefits on skill learning (Fritsch et al., 2010). Other indirect mechanisms cannot be ruled out, such as the impact of tDCS on cortical blood perfusion (Wachter et al., 2011; Stagg et al., 2013).

\section{LIMITATIONS AND FUTURE DIRECTIONS}

One outstanding question in the above-mentioned studies is: where does the current flow? Considering that tDCS has poor spatial resolution on brain tissue, it is important to acknowledge the limitation on the precision with which tDCS is able to target specific areas of the brain. A main issue is the difference between the electrodes used in animals and those used in clinical applications, preventing direct comparisons of current density and voltage distributions between experimental models (higher current densities are often reported in animals). Because in humans the outcome of stimulation depends of the amount of current delivered, it would be necessary to test whether similar dose-response curves occur in animals and attempt stimulation parameters more closely related to clinical studies. Another limiting factor is the considerable protocol variations particularly among animal models. This lack of standardization is deleterious and could contribute to the discrepancy sometimes observed in the literature. The standardization of physical parameters, namely the current density and shape, electrodes size, shape and localization (2 epicranial electrodes vs. 1 epicranial/ 1 outside the skull), the duration and number of stimulations, and the state of animals during the stimulation (awake or anesthetized) would greatly aid in the elucidation of the mechanisms and efficacy of tDCS.

Another often overlooked point is the population on which tDCS is used. The interaction of stimulation polarity, cognitive domain and other intra- and interindividual variables such as anatomic or genetic factors (Plewnia et al., 2013; Kim et al., 2014), personality (Pena-Gomez et al., 2011; Pripfl et al., 2013), cognitive strategy (Berryhill and Jones, 2012) and baseline neuronal activation state (Jacobson et al., 2012) need to be taken into consideration. Likewise, the age at which electrical stimulation occurs (Kessler et al., 2013) might be a key determinants for the physiological and behavioral outcomes of the stimulation. tDCS effects might for example be stronger/different and possibly harmful if applied to the brain during a critical stage of development such as during adolescence when the prefrontal cortex is still not fully mature.

Finally, further basic research is needed to elucidate the duration of the effects of tDCS on memory, which require evaluations at different time-points. The eventual necessity to re-stimulate the brain to maintain the beneficial effects of tDCS has yet to be investigated.

In conclusion, the data reported here are very promising and show that electrical stimulation of the brain is able to improve cognition in humans, in both healthy and in patients with psychiatric or neurological disorders. However, before it can be applied as a therapeutic tool, there is a clear need for method standardization and for a better understanding of its mode of action through the combined use of clinical research and animal models.

\section{ACKNOWLEDGMENT}

We would like to warmly thank Adriana Caballero for proofreading and editing the manuscript.

\section{REFERENCES}

Amadi, U., Ilie, A., Johansen-Berg, H., and Stagg, C. J. (2013). Polarity-specific effects of motor transcranial direct current stimulation on fMRI resting state networks. Neuroimage 88C, 155-161. doi: 10.1016/j.neuroimage.2013.11.037

Andrews, S. C., Hoy, K. E., Enticott, P. G., Daskalakis, Z. J., and Fitzgerald, P. B. (2011). Improving working memory: the effect of combining cognitive activity and anodal transcranial direct current stimulation to the left dorsolateral prefrontal cortex. Brain Stimul. 4, 84-89. doi: 10.1016/j.brs.2010.06.004

Bekinschtein, P., Cammarota, M., Katche, C., Slipczuk, L., Rossato, J. I., Goldin, A., et al. (2008). BDNF is essential to promote persistence of longterm memory storage. Proc. Natl. Acad. Sci. U.S.A. 105, 2711-2716. doi: 10.1073/pnas.0711863105

Berryhill, M. E., and Jones, K. T. (2012). tDCS selectively improves working memory in older adults with more education. Neurosci. Lett. 521, 148-151. doi: 10.1016/j.neulet.2012.05.074

Binder, S., Berg, K., Gasca, F., Lafon, B., Parra, L. C., Born, J., et al. (2014a). Transcranial slow oscillation stimulation during sleep enhances memory consolidation in rats. Brain Stimul. 7, 508-515. doi: 10.1016/j.brs.2014.03.001

Binder, S., Rawohl, J., Born, J., and Marshall, L. (2014b). Transcranial slow oscillation stimulation during NREM sleep enhances acquisition of the radial maze task and modulates cortical network activity in rats. Front. Behav. Neurosci. 7:220. doi: 10.3389/fnbeh.2013.00220

Boggio, P. S., Ferrucci, R., Rigonatti, S. P., Covre, P., Nitsche, M., Pascual-Leone, A., et al. (2006). Effects of transcranial direct current stimulation on working memory in patients with Parkinson's disease. J. Neurol. Sci. 249, 31-38. doi: 10.1016/j.jns.2006.05.062

Boggio, P. S., Khoury, L. P., Martins, D. C., Martins, O. E., De Macedo, E. C., and Fregni, F. (2009). Temporal cortex direct current stimulation enhances performance on a visual recognition memory task in Alzheimer disease. J. Neurol. Neurosurg. Psychiatr. 80, 444-447. doi: 10.1136/jnnp.2007.141853

Brunoni, A. R., Zanao, T. A., Ferrucci, R., Priori, A., Valiengo, L., De Oliveira, J. F., et al. (2013). Bifrontal tDCS prevents implicit learning acquisition in antidepressant-free patients with major depressive disorder. Prog. Neuropsychopharmacol. Biol. Psychiatry 43, 146-150. doi: 10.1016/j.pnpbp.2012.12.019

Castren, E., and Rantamaki, T. (2010). The role of BDNF and its receptors in depression and antidepressant drug action: reactivation of developmental plasticity. Dev. Neurobiol. 70, 289-297. doi: 10.1002/dneu.20758

Cotelli, M., Manenti, R., Brambilla, M., Petesi, M., Rosini, S., Ferrari, C., et al. (2014). Anodal tDCS during face-name associations memory training in Alzheimer's patients. Front. Aging Neurosci. 6:38. doi: 10.3389/fnagi.2014.00038

Dayan, E., Censor, N., Buch, E. R., Sandrini, M., and Cohen, L. G. (2013). Noninvasive brain stimulation: from physiology to network dynamics and back. Nat. Neurosci. 16, 838-844. doi: 10.1038/nn.3422

Deng, W., Aimone, J. B., and Gage, F. H. (2010). New neurons and new memories: how does adult hippocampal neurogenesis affect learning and memory? Nat. Rev. Neurosci. 11, 339-350. doi: 10.1038/nrn2822

Dockery, C. A., Liebetanz, D., Birbaumer, N., Malinowska, M., and Wesierska, M. J. (2011). Cumulative benefits of frontal transcranial direct current stimulation on visuospatial working memory training and skill learning in rats. Neurobiol. Learn. Mem. 96, 452-460. doi: 10.1016/j.nlm.2011.06.018

Eisch, A. J., and Petrik, D. (2012). Depression and hippocampal neurogenesis: a road to remission? Science 338, 72-75. doi: 10.1126/science.1222941

Ferrucci, R., Bortolomasi, M., Vergari, M., Tadini, L., Salvoro, B., Giacopuzzi, M., et al. (2009). Transcranial direct current stimulation in severe, drug-resistant major depression. J. Affect. Disord. 118, 215-219. doi: 10.1016/j.jad.2009.02.015

Fregni, F., Boggio, P. S., Nitsche, M., Bermpohl, F., Antal, A., Feredoes, E., et al. (2005). Anodal transcranial direct current stimulation of prefrontal cortex enhances working memory. Exp. Brain Res. 166, 23-30. doi: 10.1007/s00221005-2334-6

Fregni, F., Boggio, P. S., Nitsche, M. A., Marcolin, M. A., Rigonatti, S. P., and Pascual-Leone, A. (2006). Treatment of major depression with transcranial direct current stimulation. Bipolar Disord. 8, 203-204. doi: 10.1111/j.13995618.2006.00291.x 
Fritsch, B., Reis, J., Martinowich, K., Schambra, H. M., Ji, Y., Cohen, L. G., et al. (2010). Direct current stimulation promotes BDNF-dependent synaptic plasticity: potential implications for motor learning. Neuron 66, 198-204. doi: 10.1016/j.neuron.2010.03.035

Gladwin, T. E., Den Uyl, T. E., Fregni, F. F., and Wiers, R. W. (2012a). Enhancement of selective attention by tDCS: interaction with interference in a Sternberg task. Neurosci. Lett. 512, 33-37. doi: 10.1016/j.neulet.2012.01.056

Gladwin, T. E., Den Uyl, T. E., and Wiers, R. W. (2012b). Anodal tDCS of dorsolateral prefontal cortex during an Implicit Association Test. Neurosci. Lett. 517, 82-86. doi: 10.1016/j.neulet.2012.04.025

Goder, R., Baier, P. C., Beith, B., Baecker, C., Seeck-Hirschner, M., Junghanns, K., et al. (2013). Effects of transcranial direct current stimulation during sleep on memory performance in patients with schizophrenia. Schizophr. Res. 144, 153-154. doi: 10.1016/j.schres.2012.12.014

Hammer, A., Mohammadi, B., Schmicker, M., Saliger, S., and Munte, T. F. (2011). Errorless and errorful learning modulated by transcranial direct current stimulation. BMC Neurosci. 12:72. doi: 10.1186/1471-2202-12-72

Hoy, K. E., Arnold, S. L., Emonson, M. R., Daskalakis, Z. J., and Fitzgerald, P. B. (2014). An investigation into the effects of tDCS dose on cognitive performance over time in patients with schizophrenia. Schizophr. Res. 155, 96-100. doi: 10.1016/j.schres.2014.03.006

Islam, N., Moriwaki, A., Hattori, Y., Hayashi, Y., Lu, Y. F., and Hori, Y. (1995). c-Fos expression mediated by N-methyl-D-aspartate receptors following anodal polarization in the rat brain. Exp. Neurol. 133, 25-31. doi: 10.1006/exnr.1995.1004

Jacobson, L., Koslowsky, M., and Lavidor, M. (2012). tDCS polarity effects in motor and cognitive domains: a meta-analytical review. Exp. Brain Res. 216, 1-10. doi: 10.1007/s00221-011-2891-9

Jo, J. M., Kim, Y. H., Ko, M. H., Ohn, S. H., Joen, B., and Lee, K. H. (2009). Enhancing the working memory of stroke patients using tDCS. Am. J. Phys. Med. Rehabil. 88, 404-409. doi: 10.1097/PHM.0b013e3181a0e4cb

Kamida, T., Kong, S., Eshima, N., Abe, T., Fujiki, M., and Kobayashi, H. (2011). Transcranial direct current stimulation decreases convulsions and spatial memory deficits following pilocarpine-induced status epilepticus in immature rats. Behav. Brain Res. 217, 99-103. doi: 10.1016/j.bbr.2010.08.050

Kang, E. K., Baek, M. J., Kim, S., and Paik, N. J. (2009). Non-invasive cortical stimulation improves post-stroke attention decline. Restor. Neurol. Neurosci. 27, 645-650. doi: 10.3233/RNN-2009-0514

Keeser, D., Meindl, T., Bor, J., Palm, U., Pogarell, O., Mulert, C., et al. (2011a). Prefrontal transcranial direct current stimulation changes connectivity of resting-state networks during fMRI. J. Neurosci. 31, 15284-15293. doi: 10.1523/JNEUROSCI.0542-11.2011

Keeser, D., Padberg, F., Reisinger, E., Pogarell, O., Kirsch, V., Palm, U., et al. (2011b). Prefrontal direct current stimulation modulates resting EEG and event-related potentials in healthy subjects: a standardized low resolution tomography (sLORETA) study. Neuroimage 55, 644-657. doi: 10.1016/j.neuroimage.2010.12.004

Kessler, S. K., Minhas, P., Woods, A. J., Rosen, A., Gorman, C., and Bikson, M. (2013). Dosage considerations for transcranial direct current stimulation in children: a computational modeling study. PLOS ONE 8:e76112. doi: 10.1371/journal.pone.0076112

Kim, J. H., Kim, D. W., Chang, W. H., Kim, Y. H., Kim, K., and Im, C. H. (2014). Inconsistent outcomes of transcranial direct current stimulation may originate from anatomical differences among individuals: electric field simulation using individual MRI data. Neurosci. Lett. 564, 6-10. doi: 10.1016/j.neulet.2014.01.054

Kincses, T. Z., Antal, A., Nitsche, M. A., Bartfai, O., and Paulus, W. (2004). Facilitation of probabilistic classification learning by transcranial direct current stimulation of the prefrontal cortex in the human. Neuropsychologia 42, 113-117. doi: 10.1016/S0028-3932(03)00124-6

Klempin, F., Babu, H., De Pietri Tonelli, D., Alarcon, E., Fabel, K., and Kempermann, G. (2010). Oppositional effects of serotonin receptors 5-HT1a, 2 , and $2 \mathrm{c}$ in the regulation of adult hippocampal neurogenesis. Front. Mol. Neurosci. 3:14. doi: 10.3389/fnmol.2010.00014

Lally, N., Nord, C. L., Walsh, V., and Roiser, J. P. (2013). Does excitatory fronto-extracerebral tDCS lead to improved working memory performance? F1000Research 2:219. doi: 10.12688/f1000research.2-219.v2

Liebetanz, D., Koch, R., Mayenfels, S., Konig, F., Paulus, W., and Nitsche, M. A. (2009). Safety limits of cathodal transcranial direct current stimulation in rats. Clin. Neurophysiol. 120, 1161-1167. doi: 10.1016/j.clinph.2009.01.022
Liebetanz, D., Nitsche, M. A., Tergau, F., and Paulus, W. (2002). Pharmacological approach to the mechanisms of transcranial DC-stimulation-induced aftereffects of human motor cortex excitability. Brain 125, 2238-2247. doi: 10.1093/brain/awf238

Loo, C. K., Alonzo, A., Martin, D., Mitchell, P. B., Galvez, V., and Sachdev, P. (2012). Transcranial direct current stimulation for depression: 3-week, randomised, sham-controlled trial. Br. J. Psychiatry 200, 52-59. doi: 10.1192/bjp. bp.111.097634

Manenti, R., Brambilla, M., Petesi, M., Ferrari, C., and Cotelli, M. (2013). Enhancing verbal episodic memory in older and young subjects after non-invasive brain stimulation. Front. Aging Neurosci. 5:49. doi: 10.3389/fnagi.2013.00049

Marquez-Ruiz, J., Leal-Campanario, R., Sanchez-Campusano, R., MolaeeArdekani, B., Wendling, F., Miranda, P. C., et al. (2012). Transcranial directcurrent stimulation modulates synaptic mechanisms involved in associative learning in behaving rabbits. Proc. Natl. Acad. Sci. U.S.A. 109, 6710-6715. doi: 10.1073/pnas.1121147109

Marshall, L., Molle, M., Siebner, H. R., and Born, J. (2005). Bifrontal transcranial direct current stimulation slows reaction time in a working memory task. BMC Neurosci. 6:23. doi: 10.1186/1471-2202-6-23

Mulquiney, P. G., Hoy, K. E., Daskalakis, Z. J., and Fitzgerald, P. B. (2011). Improving working memory: exploring the effect of transcranial random noise stimulation and transcranial direct current stimulation on the dorsolateral prefrontal cortex. Clin. Neurophysiol. 122, 2384-2389. doi: 10.1016/j.clinph.2011.05.009

Ohn, S. H., Park, C. I., Yoo, W. K., Ko, M. H., Choi, K. P., Kim, G. M., et al. (2008). Time-dependent effect of transcranial direct current stimulation on the enhancement of working memory. Neuroreport 19, 43-47. doi: 10.1097/WNR.0b013e3282f2adfd

Oliveira, J. F., Zanao, T. A., Valiengo, L., Lotufo, P. A., Bensenor, I. M., Fregni, F., et al. (2013). Acute working memory improvement after tDCS in antidepressant-free patients with major depressive disorder. Neurosci. Lett. 537, 60-64. doi: 10.1016/j.neulet.2013.01.023

Palm, U., Fintescu, Z., Obermeier, M., Schiller, C., Reisinger, E., Keeser, D., et al. (2013). Serum levels of brain-derived neurotrophic factor are unchanged after transcranial direct current stimulation in treatment-resistant depression. J. Affect. Disord. 150, 659-663. doi: 10.1016/j.jad.2013.03.015

Palm, U., Schiller, C., Fintescu, Z., Obermeier, M., Keeser, D., Reisinger, E., et al. (2012). Transcranial direct current stimulation in treatment resistant depression: a randomized double-blind, placebo-controlled study. Brain Stimul. 5, 242-251. doi: 10.1016/j.brs.2011.08.005

Park, S. H., Koh, E. J., Choi, H. Y., and Ko, M. H. (2013). A double-blind, shamcontrolled, pilot study to assess the effects of the concomitant use of transcranial direct current stimulation with the computer assisted cognitive rehabilitation to the prefrontal cortex on cognitive functions in patients with stroke. J. Korean Neurosurg. Soc. 54, 484-488. doi: 10.3340/jkns.2013.54.6.484

Paulus, W. (2004). Outlasting excitability shifts induced by direct current stimulation of the human brain. Suppl. Clin. Neurophysiol. 57, 708-714. doi: 10.1016/S1567-424X(09)70411-8

Paxinos, G., and Franklin, K. (2001). The Mouse Brain in Stereotaxic Coordinate, 2nd Edn. San Diego, CA; London: Academic Press.

Pedron, S., Monnin, J., Haffen, E., Sechter, D., and Van Waes, V. (2014). Repeated transcranial direct current stimulation prevents abnormal behaviors associated with abstinence from chronic nicotine consumption. Neuropsychopharmacology 39, 981-988. doi: 10.1038/npp.2013.298

Pena-Gomez, C., Vidal-Pineiro, D., Clemente, I. C., Pascual-Leone, A., and BartresFaz, D. (2011). Down-regulation of negative emotional processing by transcranial direct current stimulation: effects of personality characteristics. PLoS ONE 6:e22812. doi: 10.1371/journal.pone.0022812

Pereira, J. B., Junque, C., Bartres-Faz, D., Marti, M. J., Sala-Llonch, R., Compta, Y., et al. (2013). Modulation of verbal fluency networks by transcranial direct current stimulation (tDCS) in Parkinson's disease. Brain Stimul. 6, 16-24. doi: 10.1016/j.brs.2012.01.006

Plewnia, C., Zwissler, B., Langst, I., Maurer, B., Giel, K., and Kruger, R. (2013). Effects of transcranial direct current stimulation (tDCS) on executive functions: influence of COMT Val/Met polymorphism. Cortex 49, 1801-1807. doi: 10.1016/j.cortex.2012.11.002

Pripfl, J., Neumann, R., Kohler, U., and Lamm, C. (2013). Effects of transcranial direct current stimulation on risky decision making are mediated by 'hot' and 
'cold' decisions, personality, and hemisphere. Eur. J. Neurosci. 38, 3778-3785. doi: 10.1111/ejn.12375

Stagg, C. J., and Johansen-Berg, H. (2013). Studying the effects of transcranial direct-current stimulation in stroke recovery using magnetic resonance imaging. Front. Hum. Neurosci. 7:857. doi: 10.3389/fnhum.2013.00857

Stagg, C. J., Lin, R. L., Mezue, M., Segerdahl, A., Kong, Y., Xie, J., et al. (2013). Widespread modulation of cerebral perfusion induced during and after transcranial direct current stimulation applied to the left dorsolateral prefrontal cortex. J. Neurosci. 33, 11425-11431. doi: 10.1523/JNEUROSCI.3887-12.2013

Stagg, C. J., and Nitsche, M. A. (2011). Physiological basis of transcranial direct current stimulation. Neuroscientist 17, 37-53. doi: 10.1177/1073858410386614

Takano, Y., Yokawa, T., Masuda, A., Niimi, J., Tanaka, S., and Hironaka, N. (2011). A rat model for measuring the effectiveness of transcranial direct current stimulation using fMRI. Neurosci. Lett. 491, 40-43. doi: 10.1016/j.neulet.2011. 01.004

Teo, F., Hoy, K. E., Daskalakis, Z. J., and Fitzgerald, P. B. (2011). Investigating the role of current strength in tDCS modulation of working memory performance in healthy controls. Front. Psychiatry 2:45. doi: 10.3389/fpsyt.2011.00045

Vercammen, A., Rushby, J. A., Loo, C., Short, B., Weickert, C. S., and Weickert, T. W. (2011). Transcranial direct current stimulation influences probabilistic association learning in schizophrenia. Schizophr. Res. 131, 198-205. doi: 10.1016/j.schres.2011.06.021

Vithlani, M., Hines, R. M., Zhong, P., Terunuma, M., Hines, D. J., Revilla-Sanchez, R., et al. (2013). The ability of BDNF to modify neurogenesis and depressivelike behaviors is dependent upon phosphorylation of tyrosine residues 365/367 in the GABA(A)-receptor gamma2 subunit. J. Neurosci. 33, 15567-15577. doi: 10.1523/JNEUROSCI.1845-13.2013

Wachter, D., Wrede, A., Schulz-Schaeffer, W., Taghizadeh-Waghefi, A., Nitsche, M. A., Kutschenko, A., et al. (2011). Transcranial direct current stimulation induces polarity-specific changes of cortical blood perfusion in the rat. Exp. Neurol. 227, 322-327. doi: 10.1016/j.expneurol.2010.12.005
Wolkenstein, L., and Plewnia, C. (2013). Amelioration of cognitive control in depression by transcranial direct current stimulation. Biol. Psychiatry 73 , 646-651. doi: 10.1016/j.biopsych.2012.10.010

Wood, J. N., and Grafman, J. (2003). Human prefrontal cortex: processing and representational perspectives. Nat. Rev. Neurosci. 4, 139-147. doi: 10.1038/ nrn1033

Yoon, K. J., Oh, B. M., and Kim, D. Y. (2012). Functional improvement and neuroplastic effects of anodal transcranial direct current stimulation (tDCS) delivered 1 day vs. 1 week after cerebral ischemia in rats. Brain Res. 1452, 61-72. doi: 10.1016/j.brainres.2012.02.062

Zwissler, B., Sperber, C., Aigeldinger, S., Schindler, S., Kissler, J., and Plewnia, C. (2014). Shaping memory accuracy by left prefrontal transcranial direct current stimulation. J. Neurosci. 34, 4022-4026. doi: 10.1523/JNEUROSCI.540713.2014

Conflict of Interest Statement: The authors declare that the research was conducted in the absence of any commercial or financial relationships that could be construed as a potential conflict of interest.

Received: 01 June 2014; accepted: 13 August 2014; published online: 04 September 2014.

Citation: Bennabi D, Pedron S, Haffen E, Monnin J, Peterschmitt $Y$ and Van Waes V (2014) Transcranial direct current stimulation for memory enhancement: from clinical research to animal models. Front. Syst. Neurosci. 8:159. doi: 10.3389/fnsys.2014.00159 This article was submitted to the journal Frontiers in Systems Neuroscience.

Copyright () 2014 Bennabi, Pedron, Haffen, Monnin, Peterschmitt and Van Waes. This is an open-access article distributed under the terms of the Creative Commons Attribution License (CC BY). The use, distribution or reproduction in other forums is permitted, provided the original author(s) or licensor are credited and that the original publication in this journal is cited, in accordance with accepted academic practice. No use, distribution or reproduction is permitted which does not comply with these terms. 